https://helda.helsinki.fi

\title{
Hume in and out of Scottish context
}

\section{Tolonen, Mikko}

Oxford University Press

2015

Tolonen , M \& Harris , J A 2015 , Hume in and out of Scottish context . in G Graham , A Garrett \& J Harris (eds) , Scottish Philosophy in the Eighteenth Century, : Volume I: Morals, Politics, Art, Religion . vol. 1 , Oxford University Press . https://doi.org/10.1093/acprof:oso/9780199560677.003.0006

http://hdl.handle.net/10138/159848

https://doi.org/10.1093/acprof:oso/9780199560677.003.0006

cc_by

submittedVersion

Downloaded from Helda, University of Helsinki institutional repository.

This is an electronic reprint of the original article.

This reprint may differ from the original in pagination and typographic detail.

Please cite the original version. 


\title{
HUME IN AND OUT OF SCOTTISH CONTEXT
}

\author{
James A. Harris and Mikko Tolonen
}

1.1 David Hume was a man of letters intent on erasing all trace of his Scottishness from his books. He was acutely sensitive to the differences between Scots and English, and sought tirelessly to ensure that each new edition of his works was more 'correct' than the last. From the first, he wanted a British, not just a Scottish, readership for what he wrote, and he was always keen also to have his books translated into French, the language of the international republic of letters. After the success across Europe of the Political Discourses of 1752, Hume wrote with an international audience in mind. At one point in his life, in fact, he thought of Paris as his natural home. When his friendship with Jean-Jacques Rousseau collapsed into acrimony and slander in the spring of 1766, Hume's first concern was for the consequences that Rousseau's lies might have for his reputation in France. He had his account of the affair published in French first. That Hume had been in Paris as de facto secretary to the British ambassador is evidence of the status his writings won for him in the British state, as is the fact that he was soon afterwards appointed to an important position of the Northern Department. He came to move easily in the highest circles, in London and abroad. Unlike most of those who took part in what we now call 'the Scottish Enlightenment' Hume had no investment in any of the institutions that had been identified at the time of the Act of Union as impossible to merge with their English counterparts. He never had a position of any kind in either the Scottish church, the Scottish universities, or the Scottish legal establishment. He showed little interest in the great practical projects of improvement that so concerned men like the Earl of Ilay, William Robertson, and Lord Kames. When an attempt was made to alleviate the dire financial circumstances of many of Scotland's ministers, Hume's response was to write a mocking pamphlet (see Stewart 1997).

1.2 Even so, Hume lived out of Scotland for fewer than ten years out of sixtyfive. He was educated there, and, so far as we know, did not leave the country until he was twenty-three. He returned to North Britain with relief in 1769, resolving never to go south again. All of his closest friends -- the friends to whom he wrote the most letters over the longest periods of time -- were Scottish. He knew almost everyone who was anyone in Scotland, especially in Edinburgh. He repeatedly found himself involved in Scottish party politics, and in a struggle between religious traditionalists and their modernizing antagonists. He shared drafts of his books with Scottish friends, hoping for comment and criticism. Some of his books seem to have grown out of papers presented to Scotland's numerous discussion societies. Most of his works were published in London, but, after the Treatise, were always printed and sold by Scottish publishers. There is a question to be asked, then, about the extent to which, despite his effacement of his Scottishness from his writings, Scotland imprinted itself on his books. This chapter considers some of Hume's major works with that question in mind. We begin with $A$ Treatise of Human Nature. We then consider the volumes of Essays, Moral and Political published by Hume in the 1740s. After that we turn to Political Discourses. Next we discuss The History of England -- which, of course, was at first a history of Great Britain. And we conclude with Hume's principal writings on religion, Dialogues concerning Natural Religion and 'The Natural History of Religion'. We make suggestions about the extent to which the conception and writing of each of these works might be said to have had a significant Scottish context. Hume cannot be turned into a Scottish philosopher and historian, 
where 'Scottish' means 'Scottish, not British'. Even so, the fact that he was Scottish was not irrelevant to what he wrote, and how he wrote about it.

2.1 The little we know about the composition of $A$ Treatise of Human Nature suggests that its central idea, the idea of a new, properly 'experimental' account of human nature taken as a whole, took shape in Hume's mind in the wake of the sudden mental and physical breakdown that he suffered in 1729 . In a letter written in 1751 Hume said that $A$ Treatise of Human Nature was 'plan'd before I was one and twenty, \& compos'd before twenty five' (Greig 1932: I 158). Hume turned twenty-one in April 1732. It was in 1731, so he told an anonymous physician in a long letter written in 1734 , that he had 'resolved to make [human nature] my principal Study, \& the source from which I wou'd derive every Truth in Criticism as well as Morality' (Greig 1932: I 16). It is true that in the 'Advertisement' attached to the posthumous 1777 edition of An Enquiry concerning Human Understanding, Hume described the Treatise as 'A work which the Author had projected before he left College' (Hume 1777b: I [ii]), but it seems most unlikely that Hume really did have a clear idea of what he would attempt in the Treatise while he was still a student at Edinburgh. This, however, is not to say that his four years at college need be judged to have been completely irrelevant to its conception. The logic course that he took in his third year, taught by Colin Drummond, was so old-fashioned in its concentration upon scholastic logic and semantics (see Stewart 2005: 11-16) that it might well have provoked an intelligent and independent-minded student into enthusiastic acceptance of the Lockean philosophical revolution. It might have made it seem obvious to Hume that the proper task for the logician was the study of how it is that human beings actually reason. And the course in natural philosophy that he took in his fourth year might have inspired a commitment to just the kind of Boylean and Newtonian experimentalism that Hume deployed ostentatiously throughout the Treatise -- and that he advertised on the book's title-page. $^{1}$

2.2 In the years immediately following his undergraduate studies Hume studied law for a time -- we now know that he attended law classes at Edinburgh (see Zachs 2011: 59) -- but it did not suit him. His family left him free to indulge the 'passion for literature' that in 'My Own Life', the brief autobiography written shortly before he died, Hume described as 'the ruling passion of my life, and the great source of my enjoyments' (Hume 1777a: 4). In 1729, so he told the anonymous physician, he experienced a dramatic rush of self-confidence in his literary talents: 'there seem'd to be open'd up to me a new Scene of Thought, which transported me beyond Measure, \& made me, with an Ardor natural to young men, throw up every other Pleasure or Business to apply entirely to it' (Greig 1932: I 13). Norman Kemp Smith speculated that this 'new scene of thought' was the idea of applying to logic, the study of the understanding, the sentimentbased theory of moral judgment developed by Francis Hutcheson (Kemp Smith 1941: 12-20). A closer reading of the letter to the physician makes it seem, rather, that this

\footnotetext{
${ }^{1}$ Hume's name is on a list of students 'who contributed to the augmenting' of a 'Physiological Library' founded by the professor of natural philosophy, Robert Steuart, in 1724 (Anon. 1725: 8; for an analysis of the library catalogue, see Barfoot 1990).
} 
moment of inspiration was a false start, that it was not until two years later that the idea of the Treatise came into focus, and that what animated Hume in 1731 was a conviction that the respect for ancient philosophy so plain in Hutcheson's works was a fertile source of error (see Brandt 1977). Hutcheson was surely one of those who had been 'overthrown' by the greatness of the genius of the ancients. Hume resolved to 'throw off' all such 'prejudices' (Greig 1732: I 16).

2.3 In 1731 Hume was still living at the family home of Ninewells in Chirnside, close to Berwick upon Tweed and the border with England. The Borders was then, as it is now, a relatively sparsely populated region, but in the early 1730s it was even so the site of a considerable amount of philosophical activity. Henry Home of Kames had his own family home near to Chirnside, and doubtless spent time there while the Edinburgh law courts were closed. Kames had by this time had philosophical correspondence with Samuel Clarke and Joseph Butler, and also with another inhabitant of the Scottish Borders, the religious controversialist, and defender of Clarke's views, Andrew Baxter. At this point in his career Kames was writing a good deal more than he published, on a variety of subjects, in logic and metaphysics, morals, politics, and criticism. According to James McCosh Hume and Kames became acquainted as early as 1727 (McCosh 1875: 174), though the earliest surviving letters are dated ten years later. It is likely that they were debating a wide range philosophical and literary questions between 1731 and 1734, while Hume 'scribled many a Quire of Paper, in which there is nothing contain'd but my own Inventions' (Greig 1932: I 16). Kames was the older man by fifteen years, and his example and his encouragement would have been important to Hume, as it was to others later. In 1745 Hume would tell Kames that he had always regarded him 'as the best Friend, in every respect, I ever possest' (Klibansky and Mossner 1954: 17). Also close by was the deist William Dudgeon, who on account of his State of the Moral World Consider'd was summoned before the presbytery of Chirnside in 1732. The case was referred up to the General Assembly of the Church of Scotland, and dragged on until 1736, when it was finally dropped. Dudgeon was attacked in print by Baxter, and published in turn a vindication of his claim that when the scheme of providence is properly understood, it can be seen that there is no real evil in the universe, neither moral nor physical. Hume must have been aware of Dudgeon and of the fate of his book. In a copy of his Philosophical Works (1765) held by the National Library of Scotland that contains Dudgeon's own annotations someone wrote that 'David Hume owed many hints contained in his writings to Mr. Dudgeon'. ${ }^{2}$ This is not entirely plausible. Hume never entertained Dudgeon's kind of quasi-Spinozist metaphysics, and, Section VIII of the first Enquiry, explicitly criticized the kind of theodicy outlined in the State of the Moral World Consider'd. ${ }^{3}$

2.4 In so far as it is possible responsibly to form any hypothesis at all about Hume's intellectual influences in the early 1730s, it would seem that it was Bernard

\footnotetext{
${ }^{2}$ NLS [Ven].9/2

${ }^{3}$ There is in fact nothing very remarkable about Dudgeon's views. In many respects they are similar to the opinions of writers such as Hutcheson, William Leechman, and George Turnbull. Dudgeon's prosecution is evidence merely of the antipathy of traditionalist Calvinists to new styles of moral and religious thought. Claims made by Paul Russell (in Russell 2008: ch. 4) to the effect that the Dudgeon-Baxter debate must have been vitally important to Hume as he planned the Treatise depend upon the plausibility of the idea that Hume's principal goal in his first book was to replace the philosophy of Samuel Clarke with a materialist, atheistic neo-Hobbesianism. For reasons to be sceptical of this idea, see Harris (2009).
} 
Mandeville who played the most important role. There are echoes of Mandeville in all of the most important surviving texts from this period: the incomplete manuscript 'An historical essay on chivalry and modern honour' (see Wright 2012), the letter to the anonymous physician (see Wright 2003), and a letter written in France from Hume to his friend Michael Ramsay (see Tolonen 2008). And if, as seems likely, Mandeville retained a hold over Hume during the composition of the Treatise, we have the beginnings of an explanation as to why it is impossible to locate Hume's first book in the 'providential naturalist' (or 'teleological naturalist') tradition identified by David Fate Norton as the mainstream of eighteenth-century Scottish philosophical thought (see Norton 1982: 2024 and passim; also Norton XXXX). Hume's Scottish contemporaries -- from Hutcheson and Kames through to Beattie and Reid -- understood the task of the scientist of human nature to be that of revealing divine wisdom and benevolence at work in the framing of the mind and its powers. God was believed to have had a purpose in his design of human nature. That is, God had an idea of human happiness and of how it was best achieved, and the philosopher's job was to interpret human nature as evidence of the creator's intentions. Conceived of this way, the science of the mind was at the same time a means of bolstering confidence in the reliability of our epistemic and moral faculties. Like Mandeville, Hume rejected this picture of philosophy altogether. Consideration of purposes and 'final causes' had no more place in the study of human nature than in the study of physical nature. The philosopher was better compared to the anatomist, who, when he pulled off the skin and began to cut up mussels, flesh, and organs, revealed things more likely to revolt than delight. Mandeville had presented himself in this way on the very first page of The Fable of the Bees, and Hume borrowed Mandeville's imagery in a letter to Hutcheson written in 1739 (Greig 1934: I 32-3), and also in the final paragraph of Book Three of the Treatise (Hume 1739-40: III 280-1). Hume presumably intended himself to be understood as doing something quite different in philosophy from what was being done by his Scottish contemporaries.

2.5 In the Introduction to the Treatise Hume located himself in an English tradition of 'philosophers ... who have begun to put the science of man on a new footing, and have engaged the attention, and have engaged the curiosity of the public' (Hume 1739-40: I 6-7). He does so again in the Abstract ... of $A$ Treatise of Human Nature, published in 1740 in order to stir up interest in a book that Hume, with a first-time author's anxiety, was sure was not getting the attention it deserved. 'This book', the Abstract begins, 'seems to be wrote upon the same plan with several other works that have had a great vogue of late years in England' (Hume 1740: 5; italics in the original). Here, presumably, by 'English' and 'England' is meant 'Britain' and 'British' -- where 'Britain' includes Ireland as well as England and Scotland. Locke, Shaftesbury, Mandeville, Hutcheson and Butler are referred to in the Abstract as 'our countrymen', 'who, tho' they differ in many points among themselves, seem all to agree in founding their accurate disquisitions of human nature entirely upon experience' (Hume 1740: 7). Elsewhere in the Abstract, though, Hume makes it clear that he does not see his philosophy as British and British only. The Abstract intimates that the main contribution of the Treatise is the account of probabilistic reasoning developed in Part Three of Book One. It was Leibniz, Hume says, who, in his Théodicée, pointed out the inadequacy of what little attention had been given to probabilistic as opposed to demonstrative inferences. And the failing that Leibniz identified was a failing to be found not only in Locke, but also in Malebranche and in the logic of Arnauld and Nicole. The principal argument of the Treatise, in other words, had European significance. Hume underlines this with references elsewhere in the Abstract to Descartes and Cartesian doctrine. There are not many references to other writers in the Treatise itself, but there is a perhaps rather studied cosmopolitanism to mentions of Malezieu, La Rochefoucauld, Rollin and Guicciardini in addition to Berkeley, 
Barrow, Milton and Prior. Hume intended it to make it plain that the author of the Treatise had read widely in French and Italian as well as in English.

2.6 '[W] hen St. Denis is mentioned,' Hume observes in the Abstract, 'the idea of Paris naturally occurs' (Hume 1740: 32). The Treatise was written in France, and Book One in particular seems to have been shaped by sceptical currents of thought much more powerful there than in Britain. It might be that Hume had been, so to speak, prepared by his Calvinist upbringing to find scepticism more plausible than most of his British contemporaries did. However, it is entirely possible that the fact that Hume went to France in 1734 made the Treatise a different book from what it would have been had Hume returned to Ninewells after his brief spell as a trainee merchant in Bristol. We know that Hume encountered Bayle in 1732 at the latest (see Greig 1932: I 12) -- he could have been lead to Bayle by Mandeville's Free Thoughts concerning Religion, Government, and National Happiness -- but in France he may well have read more deeply and widely in the modern sceptical tradition. It has been argued, for example, that Pierre Daniel Huet might have had a significant impact on Hume's elaboration of sceptical argumentation (see Broadie 2012: ch. 3). In 1745 Hume would cite 'Monsieur Huet the learned Bishop of Avaranches' as proof that the most extreme scepticism was perfectly compatible with the deepest piety (Hume 1745: 20-1). There are, moreover, several places in Books One and Two of the Treatise which evince serious, and of course sceptical, engagement with the philosophy of Malebranche. In fact, considered under its sceptical rather than under its 'naturalistic' aspect, the Treatise reads like nothing so much as a pitting of modern French Pyrrhonism against modern French metaphysics.

2.7 It might be thought that Hume returns to distinctively British concerns at the beginning of Book Three, with its rehearsal of the debate between rationalist and sentimentalist theories of the foundations of morals. It might also be thought that Hume adopts a distinctively Scottish position with respect to that debate, in so far as he reiterates Hutcheson's arguments against rationalism, and presents himself as one of those who holds that moral distinctions are 'deriv'd from a moral sense', and that '[m]orality ... is more properly felt than judg'd of' (Hume 1739-40: III 26). On David Norton's reading of Hume, for instance, the gap between Hume and his Scottish contemporaries -- certainly the gap between Hume and Hutcheson -- is considerably narrower in Book Three than in Books One and Two of the Treatise (see Norton 1982: ch. 3). And Kemp Smith read Hume as having accepted wholesale Hutchesonian sentimentalism (see Kemp Smith 1941: 23-44). It is easy, though, to exaggerate the significance of Part One of Book Three when it comes to the understanding of the overall thrust of Hume's moral philosophy. It has been suggested, in fact (by James Moore: see Moore 1994: 38-9), that Part One was a late addition to the argument, an addition made after Hume had received Hutcheson's comments on his scheme of the virtues in (what would be published as) Parts Two and Three. On this interpretation, starting a book of moral philosophy with an adoption of sentimentalism was in essence a way of pre-empting criticism that was bound be excited by the subsequent argument that justice and promise-keeping are 'artificial' and not 'natural' virtues. It enabled Hume to pretend that he was doing no more than drawing out implications of the Hutchesonian view -- when in truth he was presenting an aggressive, and distinctively Mandevillean, challenge to Hutcheson's conception of the nature of the distinction between virtue and vice. Moore thus sees Book Three as no less indebted to French thought -- in this instance, to French neo-Epicureanism, as channeled by Mandeville -- in Book Three than in Books One and Two (see Moore 1994: $27-29$ and passim; see also Tolonen 2013).

2.8 Hutcheson was among those to whom Hume sent copies of Books One and Two of the Treatise. In a letter to Kames, Hutcheson declared himself 'every where 
surprised with a great acuteness of thought and reasoning in a mind wholly disengaged from the prejudices of the Learned as well as those of the Vulgar' (Ross 1966: 71). But even this early in his career Hume was not writing with only a local Scottish audience in mind. Copies were also sent, for example, to Butler and to Pope. Hume seems to have been especially concerned to know what Pierre Desmaizeaux thought of the Treatise. 'Have you found it sufficiently intelligible?' Hume asked. 'Does it appear true to you? Do the Style \& Language seem tolerable?' (Greig 1932: I 29). Desmaizeaux, editor of Bayle, editor also of the Bibliothèque raisonée des ouvrages des savans de l'Europe, was a conduit whereby Hume might make himself known to the larger pan-European republic of letters. By the middle of the 1740s, when Hume had given up on the Treatise and on the initial idea of adding to it treatments of criticism and politics, when he was thinking afresh about how to present his philosophical ideas to the public, intelligibility and style and language remained as important as truth. It is conceivable that the way his ideas were misrepresented when he was put forward for the Edinburgh moral philosophy chair in 1744-5 (see below, Section 6 of the present chapter) helped shape the new presentation of those ideas in Philosophical Essays concerning Human Understanding (later re-titled $A n$ Enquiry concerning Human Understanding) (see Stewart 2002). Hume saw that he needed to be clearer about the nature of his scepticism, and clearer, in particular, about the fact that it was not meant to discredit the beliefs of common life. But the Philosophical Essays were no more aimed at a purely Scottish audience than the Treatise had been. They were a determined bid for recognition from all of those who admired the style of Cicero, La Bruyère and Addison as much as they did the philosophical penetration of Malebranche and Locke. The Enquiry concerning the Principles of Morals relegated to an appendix the British debate between rationalists and sentimentalists. It also downplayed its author's debts to Mandeville. It was organised instead around a question -- concerning the role of the utile and the dulce in moral judgment -- that had been given canonical form by Cicero in De officiis, a text that every educated European knew well.

3.1 In the summer of 1739 Hume was exchanging 'papers' with Kames, at least some of which later appeared in the two volumes of Essays, Moral and Political that Hume published in 1741 and 1742 (Greig 1932: I 30-31). In the Advertisement to the first volume Hume related that most of the essays 'were wrote with a View of being publish'd as WeEKLY-PAPERS' (Hume 1741: iii). It is sometimes speculated (see e.g. Ross 1972: 81; Emerson 2008: 10) that Hume and Kames were planning a new journal together. Earlier Edinburgh publishing ventures like The Echo: or, Edinburgh Weekly Journal (which had run from 1729 to 1732), The Reveur (which had run between November 1737 and May 1738) and Letters of the Critical Club (which had run from January to June 1738, and may have been partly written by Kames) had made it clear that there was a Scottish appetite and market for such journals. They were in some respects imitations of London-based publications like The Gentleman's Magazine, and in others owed much to the example Addison and Steele's Tatler and Spectator. They eschewed theological and political controversy, or at least claimed to do so, and made a show of, like Addison and Steele, concentrating instead on manners, morals, and taste. Several of Hume's essays are in a similar idiom, with similar preoccupations. And some of them show signs of being written with a specifically Scottish audience in mind. There is at one point a humorous 
reference to 'our Scottish ladies', and when Hume mentions a famous miser in 'this city', he means Edinburgh (Hume 1741: 63, 155). These essays of Hume's are evidence that by the fourth decade of the century the witty, elegant, reflective language of the Tatler and Spectator could not possibly be regarded as an alien, Anglicizing imposition -- and they are evidence also that Hume was as interested as anyone in Scotland in showing that 'politeness' was as much at home in Edinburgh as it was in London (see Phillipson 1975).

3.2 Hume's took as the model for his essays Bolingbroke's Craftsman as well as Addison and Steele's Spectator (Hume 1741: iii). The majority of the pieces collected in the first volume of Essays, Moral and Political addressed political questions. Like many other writers on politics at the time, including Bolingbroke of course, Hume was especially concerned with the factionalized state of British political life, and he carefully cultivated an balanced and non-partisan approach to the issues of the day, seeking to lower the political temperament by bringing out the respects in which the Whig government and its opposition critics were in agreement with each other. All of the political topics that Hume discussed in the Essays necessarily had at their heart the question of whether the style of parliamentary management very successfully developed by Robert Walpole amounted to a corruption of the constitution and a subversion of British liberty. Hume thought not. He argued, against Bolingbroke, that the stability of the British polity depended upon strong executive power, and that Walpole's showering of places and pensions upon Members of Parliament was in principle (though not always in practice) a justifiable means of countering what would otherwise be an overwhelmingly strong House of Commons. Preserving the settlement that had followed the Revolution of 1688 required a powerful, centralized, state apparatus. This was a position that had implications in the Scottish context. It amounted to support for the powerful regime of crown patronage managed for Walpole by Archibald Campbell, Earl of Ilay (see Emerson 2013: ch. 14). ${ }^{4}$ Even while Hume appeared in his political essays to be discussing Westminster matters, he was at the same time inserting himself into the local Scottish debate between Ilay and his opponents.

3.3 At the end of the essay 'Of the Parties of Great-Britain' Hume turned from the analysis of Britain taken as a whole to the case of Scotland in particular. The main argument of this essay is that the real distinction between Whig and Tory had not, as Bolingbroke claimed it had, been lost in 1688. The essence of the distinction was a disagreement about the relative importance of liberty and monarchy combined with a difference of views about the settlement of the crown, whether on the House of Hanover or the House of Stuart. The two party positions Hume took to be 'accidental, but natural Additions to the Principles of the Court and Country Parties, which are the genuine Parties of the British Government' (Hume 1741: 134). England and Scotland differed, however, in that 'we never had any Tories in Scotland, according to the proper Signification of the Word, and that the Division of Parties in this Country was really into Whigs and Jacobites' (Hume 1741: 138). The difference between a Tory and a Jacobite was that the latter had no regard at all for liberty and the constitution, and was either in favour of absolute monarchy, or was at least willing to sacrifice all of the 1688 settlement to ensure a Stuart succession. And what had made Jacobitism a force to be reckoned with in the earlier part of the century was the way its flames had been fanned by episcopalian clergy who had all been turned out of their churches after the Revolution

\footnotetext{
${ }^{4}$ Hume sent Ilay (since 1743 the third duke of Argyll) a copy of the 1748 edition of Essays, Moral and Political. It was a present, he said, 'not to the Duke of Argyle, but to Archibald Campbell, who is undoubtedly a Man of Sense and Learning' (Greig 1932: I 113).
} 
and so had no reason to make any kind of compromise with the new regime. But now, Hume claimed, Jacobitism was a spent force, which, in the absence of a Tory party, meant that Scotland's politics were entirely determined by the natural distinction between the parties of court and of country, a distinction which, Hume claimed, was still 'but creeping in at London' (Hume 1741: 139). There was, moreover, a further reason for the absence of a Tory-Whig divide in Scotland. In North Britain there were only two social ranks, the wealthy and educated on the one hand, and the mean and slaving poor on the other. There was no 'middling rank of men', as in England, neither in the cities nor in the country. The middling rank, according to Hume, 'have Curiosity and Knowledge enough to form Principles, but not enough to form true Ones, or correct any Prejudices that they may have imbib'd' -- 'And 'tis among the middling Rank of People, that Tory Principles do at present prevail most in England (Hume 1741: 139-40).

3.4 Hume was interested enough in Scotland to point out these differences from England, but did not discern the real significance of the fact that Scotland lacked a sizeable class of people of the middle rank. Four years after Hume claimed that 'the Jacobite Party is almost entirely vanish'd from among us' Charles Edward Stuart landed on the west coast of Scotland, gathered an army, quickly took control of Edinburgh, and then marched south into England to get within a hundred miles of the capital. It was among the wealthy and the slaving poor that Charles found most of his supporters. Hume was out of Scotland for most of the '45, employed as tutor to the marquess of Annandale at Weld Hall near St. Albans, and does not discuss it in his letters. He had his say about it though, in a pamphlet written to defend his friend Archibald Stewart from the charge that as provost of Edinburgh in 1745 he had failed to be sufficiently stalwart in the measures he took to defend the city from the Jacobite army. In the event, charges against Stewart were dropped before Hume's pamphlet could be published, but Hume put it out anyway. A True Account of the Behaviour of Archibald Stewart makes plain Hume's complete lack of sympathy for the Jacobite cause, and for the situation of Highland Scotland more generally. Had the rebels prevailed, he wrote, Britain would have been 'reduced to Slavery' (Box, Harvey, and Silverthorne 2003: 237). That this nearly happened was due to the fact that the civilized part of the country -- meaning Lowland Scotland and England -- had lost the habit of the use of arms, while 'the barbarous Highlander' still cultivated ideas of military honour and valued courage in battle above all else. Hume's pamphlet strongly suggests that he thought it was right that the British state took full and violent revenge on the regions that had given Charles Edward most support. When civilization was threatened by barbarism, Hume was absolutely sure which side he was on.

3.5 The same scepticism about the supposed virtues of an uncorrupted and martial Scotland was on display when, twenty years later, Hume was faced with the poems that James Macpherson claimed were English translations of an ancient epic poems in Gaelic by 'Ossian son of Fingal'. Having initially been willing to take Macpherson at his word (see Greig 1932: I 328-31, and Raynor 1991), Hume came to find it impossible, in the absence of any positive evidence to the contrary, not to believe that all the poems were forgeries. In the early 1770s he laid out the reasons for doubt in an unpublished paper that may have been intended for presentation at a discussion society. ${ }^{5}$ Part of that paper was then used in a letter to Gibbon. 'It is, indeed, strange,' he told the author of the Decline and Fall, 'that any men of Sense coud have imagin'd it possible, that above twenty thousand Verses, along with numberless historical Facts, could have been preservd by oral Tradition during fifty Generations, by the rudest,

\footnotetext{
${ }^{5}$ NLS MS XXX
} 
perhaps, of all European Nations; the most necessitous; the most turbulent, and the most unsettled' (Greig 1932: II 310). Those who clung to the idea of the authenticity of Macpherson's publications did so because they wanted it to be true that the poems testified to something eternal in the Scottish character. Here was an idea of Scottishness that differentiated Scotland from England, indeed from the rest of Europe, and that suggested that Scots had the resources whereby to preserve an essential strength and virtue in the face of the effeminacy and luxury of modern civilization. Hume did not value that idea of Scottishness. Though a member of the club, the Poker, formed to agitate for a Scottish militia, Hume had no real interest in preserving the military spirit among his countrymen (see Robertson 1985: 237-43). ${ }^{6}$ And when Adam Ferguson published An Essay on Civil Society in 1767, with its passionate case for the ancient virtues of simplicity and martial valour as antidotes to modern corruption, Hume was privately very disappointed in his friend. He asked Elizabeth Montagu whether the Essay 'did not savour somewhat of the country': 'Oh yes, said she, a great deal: it seems almost impossible that anyone could write such a style except a Scotchman' (Greig 1932: II 1312). This was exactly what was wrong with it. It was Scottish, not British.

3.6 As Hume saw it, both Ferguson and those who clung to the authenticity of the Ossianic poems were nostalgists who were failing to face up to political reality, and who were mistaken as to the nature of the situation that Scotland had to deal with in the second half of the eighteenth century. The defeat of Charles Edward's army at Culloden should have been taken as evidence that there was nothing worth preserving in the values and ideals of Scotland's distant past. The real issue for Scots was not to be framed in terms of the tension between those ideals and modern, British, commerce and 'corruption', but rather in terms of what the character would be of the Whig political culture that was bound to dominate Scotland for the foreseeable future. This was the issue that the trial of Archibald Stewart had brought into focus. It had been Whigs who had wanted Stewart's disgrace -- and of course Stewart himself was a Whig too. But, Hume explained in a Postscript to his pamphlet defending Stewart, there was a crucial difference between 'religious Whigs' and 'political Whigs'. A political Whig was 'a Man of Sense and Moderation, a Lover of Laws and Liberty, whose chief Regard to particular Princes and Families, is founded on a Regard to the publick Good' (Box, Harvey, and Silverthorne 2003: 251). A religious Whig, by contrast, was motivated most strongly by an antipathy to bishops and the Book of Common Prayer, and his religious zeal was all too likely to issue in 'Dissimulation, Hypocrisy, Violence, Calumny [and] Selfishness' ((Box, Harvey, and Silverthorne 2003: 252). Stewart's trial had been a return to the madness and bitterness of the seventeenth century, when Scottish Protestantism had torn itself, and the country, apart over what Hume regarded as trivial and unsettlable questions of dogma and ceremony. What was most necessary after the defeat of the Jacobites was that this history not be allowed to repeat itself. Political Whiggism, with its pragmatic focus on the public good, had to prevail over those willing to use the rebellion as an excuse to return to the religious disagreements of the past.

\footnotetext{
${ }^{6}$ The fact that Hume found a place for a militia in his design for a perfect commonwealth (see Hume 1752: 291) had no implications for the question of whether it was sensible to allow militias in Scotland barely more than a decade after the Jacobite rebellion. It was true that, as Hume put it, 'without a militia, 'tis folly to think any free government will ever have security or stability' (Hume 1752: 298) -- but Britain was a monarchy, albeit a limited one, not a free government in the republican sense of the word 'free'.
} 
3.7 The question of the form Whiggism that should take remained firmly in Hume's sights in three essays that he wrote in the immediate aftermath of the rebellion. They were intended to be published together as a small book, and to be added also to the new edition of Essays, Moral and Political that would be published in 1748. These were 'Of Passive Obedience', 'Of the Original Contract', and 'Of the Protestant Succession'. They can be understood as Hume's response to the '45. In the six pages of 'Of Passive Obedience' he provided a summary and brutally efficient demolition of the key political principle of Jacobitism. 'Of the Original Contract' was much longer, and much more carefully argued, but it was also a work of demolition. It did fatal damage to the idea that the origin of the duty of allegiance lay in a contract between the sovereign and the people -- an idea which had the corollary that when the contract was violated by the sovereign, the duty of allegiance no longer obtained, and the people had a right to resist and to replace the sovereign with a new government of their choosing. After 1688 Whiggism had had to reconfigure itself, and turn itself from an oppositional doctrine into the ideology of an apparently permanent party of government. But what, then, should be the principles of the new style of Whiggism? What was its philosophical foundation? This was the question that Hume addressed in 'Of the Protestant Succession'. And the answer was that Whiggism -- political Whiggism -- had in fact no foundation deeper than regard for the public good. Nothing had happened in 1688 or since that had instantly deprived the Stuart line of legitimacy and conferred it instead and William of Orange and his successors. The ' 45 had raised the question of whether George II really did have a title to the British crown. It was not completely obvious that he did. There was still something to be said for the Stuarts and the principle of hereditary succession. The only way of settling the matter lay in considering whether Hanoverian government was proving good for the country, whether it was (mostly) preserving peace and order, and allowing Britain to prosper. These were the terms in which Whigs needed to be thinking -- especially, perhaps, in Scotland, where religion was still likely to distract Whigs from the questions that mattered.

3.8 Hume told Kames that he treated the subject of the Hanoverian succession 'as coolly and indifferently, as I would the dispute betwixt Caesar and Pompey. The conclusion shows me a Whig, but a very sceptical one' (Greig 1732: I 111). Hume was persuaded by his friends in Scotland that sceptical Whiggism was not what was called for in a Britain still reeling from the Jacobite incursion. Sceptical Whiggism was too likely to sound like no Whiggism at all. At the time the Hanoverian succession expected more robust support than this essay provided. So Hume held it back -- it was published four years later in Political Discourses -- and wrote a new essay to be published with 'Of Passive Obedience' and 'Of the Original Contract'. This was 'Of National Characters'. It was written while Hume was in Turin as secretary to a diplomatic mission led by General St. Clair. Hume says little about Scotland in the course of his argument that national character is determined by 'moral' and not by 'physical' causes. The only reference to Scotland is by way of comparison and contrast with the 'wonderful Mixture of Manners and Character' observable in England. The implication is that Scotland is much more typical: it has a definite national character, unspecified by Hume, while 'the English, of any People in the Universe, have the least of a national Character; unless this very Singularity be made their national Character' (Hume 1748: 15-17). In a discussion of the differences between northern and southern peoples, Hume gave further evidence of his inability to believe in the moral superiority of simpler, less civilized peoples. Thus the fact that it is usually northern nations that conquer southern ones, and not vice versa, was characterized as being mostly a matter of poverty and want triumphing over plenty and riches. 'Of National Characters' was much criticized because of a footnote on the character of the priestly profession. Mossner claims that this was a covert attack on 
Scotland in particular (Mossner 1980: 234), but it might just have well been prompted by Hume's recent experience of life in Catholic countries.

4.1 Among those who took exception to the footnote attacking priests in 'Of National Characters' was Robert Wallace, an Edinburgh minister, and leader of the Church of Scotland in the early 1740s. Among Wallace's unpublished papers is a comprehensive reply to Hume vindicating the priestly profession. ${ }^{7}$ Wallace, however, was no unthinking bigot. He had been a founder member of the Rankenian Society, and was a member of Edinburgh's Philosophical Society. An opponent of the Argyll interest in Scottish affairs, he devoted himself largely to scholarship after the Duke of Ilay rose to preeminence in the wake of the '45, and in the mid-to-late 1740s he read to the Philosophical Society a Dissertation on the Numbers of Mankind in Antient and Modern Times. Wallace's position -- in large part a critique of Mandeville -- was that the population of the ancient world had been considerably greater than that of the modern, and that the explanation of the decline in the number of human beings was to be found in the corruption of manners and morals. During a two-year period spent at Ninewells between 1749 and 1751 Hume developed a contrary line of argument in his essay 'Of the Populousness of Antient Nations'. Hume read and corrected the manuscript of Wallace's Dissertation before the essay was published in Political Discourses in 1752, and their subsequent correspondence about population and other issues was for Hume a model of how enlightened men of letters should treat each other (see Klibansky and Mossner 1954: 28-35, and Mossner 1943: XXX-XXX). He made a point of acknowledging Wallace's 'erudition' and 'good reasoning' in a footnote at the beginning of the essay (Hume 1752: 155). Wallace, in turn, when he published the Dissertation in 1753, added to it a long Appendix subjecting Hume's essay to rigorous yet respectful criticism. ${ }^{8}$ Nor was Wallace the only Scot with whom Hume could differ profoundly and yet maintain friendly relations. When James Balfour criticized Hume's moral philosophy in his 1753 Delineation of Nature and Obligation of Morality, Hume wrote to him imagining that they might 'revive the happy times, when Atticius and Cassius the Epicureans, Cicero the Academic, and Brutus the Stoic, could, all of them, live in unreserved friendship together, and were insensible to all those distinctions, except so far as they furnished agreeable matter to discourse and conversation' (Greig 1932: I 173).

4.2 Discourse and conversation with his Scottish contemporaries was important to Hume. The Treatise was the only one of his works composed in intellectual and social isolation. The political economy contained in Political Discourses was talked through with James Oswald of Dunnikier -- and no doubt with Kames as well. In October 1750 Oswald wrote to Hume with some critical comments on the argument of a draft of the

\footnotetext{
7 'Letter from a Moderate Freethinker'

${ }^{8}$ It is possible that Hume also discussed the argument of 'Of Miracles' with Wallace. Among Wallace's papers is a set of 'Observations on the Account of the Miracles of the Abbé de Paris'. XXX?
} 
essay 'Of the Balance of Trade'.' These comments put pressure in particular on the scepticism expressed in that essay about the capacity of a rich country permanently to maintain its advantages over a poor country. Oswald was much more confident than Hume in a rich country's ability to rely on, especially, its capacity to buy and store cheap food in times of abundance, and to attract skilled workers. Oswald's letter seems to have been important to the final published form of 'Of the Balance of Trade'. Hume may have also found helpful the discussion -- initiated by Adam Smith -- of some of his 'Essays on Commerce' at the Literary Society of Glasgow in January 1752. There is some reason to think that the point of the title 'Political Discourses' was to draw attention to the fact that the essays the book contained presented their subject matter in a discursive manner, that is, in a manner intended to provoke further discussion. Many if not all of the questions raised in Political Discourses were already subjects of conversation in Scotland in the late 1740 s and early 1750 s.

4.3 Political Discourses, like the first editions of the Essays, Moral and Political, was published in Edinburgh. Roger Emerson has claimed that in fact Hume had a distinctively Scottish agenda in his writings on economics -- that he 'had Scots in mind for significant portions of his theoretical analyses and policy recommendations' (Emerson 2008: 10). A direct consequence of the ' 45 was that the issue of the economic development of the Highlands had at last become a pressing issue for Lowland Scots. It was felt that punitive and negative measures, such as the disarming of the Highlanders, and the abolition of military tenures and hereditary jurisdictions, were not enough to ensure the extinction of the Jacobite threat. Only if the Highlands were fully integrated with the rest of Scotland, and made equally able to benefit from the Act of Union, would the Highlanders come to feel, like the Lowlanders, that their interests lay in the preservation of the Hanoverian succession. The Highlands had to be pulled forward out of the age of feudalism and into the age of commerce. It may have been, then, that in 'Of Commerce' and 'Of Luxury' (later retitled 'Of Refinement in the Arts') Hume was addressing those of his fellow Scots who worried about the effects of such a process of modernization on manners and morals. It was not only Jacobites who had such worries. Men like Wallace, who had staunchly defended the Hanoverian cause in 1745, had them too. ${ }^{10}$ Of course this was not the only thing Hume was doing in these essays. More than ever in Political Discourses he had a pan-European audience in mind. But he would have known that this was a question that had especial resonance in Scotland in the early 1750s. Thus, as George Caffentzis has noted, in 1752, the year when Political Discourses was published, a third of the land of the Highlands was annexed by the Crown to be sold at public auction, with the provision that rent and profits were to be used for the purposes of 'civilizing' both the inhabitants of the land and those living in other parts of the Highlands and Islands of Scotland (see Caffentzis 2001: 312).

4.4 Caffentzis has suggested that Political Discourses presented the Commissioners of the Annexing Act with, in effect, an 'agenda for social reconstruction' in the Highlands that ranged 'from the material foundations to the demography to the political superstructure' (Caffentzis 2001: 313). The essay 'Of the Protestant Succession' spoke to the issue of the political superstructure. 'Of the Populousness of Ancient Nations' forged a connection between increase in the world's population with the spread of modern ideas of liberty. One of the things, Hume argued, that spoke against the view defended by Wallace was the prevalence of slavery in the ancient world. And crucial to the material

\footnotetext{
${ }^{9}$ For the full text of Oswald's letter, see XXX; an abbreviated version is printed in Rotwein 19XX: 190-96.

${ }^{10}$ Though Wallace's Address to the Jacobites in Scotland XXX
} 
foundations of economic progress was money. Hume is well known for having argued in his essay 'Of Money' that the absolute quantity of money in a nation's economy is irrelevant to its prosperity. But he also held -- and had articulated in his correspondence with Oswald (see Greig 1932: 143) -- the view that a steady increase in the supply of money is essential to growth. By this means the magistrate 'keeps a spirit of industry alive in the nation, and encreases the stock of labour, wherein consists all real power and riches' (Hume 1752: 51-59). Hume was serious in his claim that the 'stock of labour' -along with appetite for work, and skills in agriculture and manufacturing trade -- was what mattered most. In 'Of Money' he argued that poverty prevailed in 'some kingdoms, and many provinces in Europe' not because money was in short supply, but because of 'the manners and customs of the inhabitants'. Scarcity of money by itself was an irrelevance. It was not the cause of poverty, but rather one of poverty's collateral effects. Where there was vigorous economic activity, money was bound to circulate more quickly and more extensively, generating in turn yet more economic activity. In a region like the Highlands, however the question was how the spirit of industry was to be released and set to work. There were those in Scotland who thought -- as the Scottish political economist John Law had argued earlier in the century -- that banks and paper money had a crucial role to play here. Hume was at first extremely sceptical in this regard, arguing that, while in theory it did not matter what was used as money to facilitate exchange, in practice there reasons to be wary of 'those institutions of banks, funds, and paper credit, with which we are in this kingdom so infatuated' (Hume 1752: 89). They were one sure means of 'sinking money below its level'. As time passed, however, Hume's hostility to banks and paper credit weakened. By 1764 he was willing to accept that 'a right use of paper money' might succeed in producing an 'encrease of industry and of credit' (Hume 1764: I 351). Caffentzis suggests that what was responsible for this change of heart was 'the gradual dominance of paper in most transactions in Scotland and the tremendous growth of the Scottish economy based on the international tobacco boom, the increased prices for cattle, and the intensifying productivity of the linen trade' (Caffentzis 2001: $322)$.

4.5 Was Scotland's developing economy evidence that it had sufficient people and skills and enterprise to overcome the inequality apparently inherent in its relations with England? As we have seen, Hume, unlike Oswald, did not believe that a rich country could maintain its advantages indefinitely. In 'Of Money' he argued that there was hope for a poor country, at least in the short to medium term, in the cheapness of its labour. 'Manufactures, therefore,' Hume claimed, 'gradually shift their places, leaving those countries and provinces, which they have already enrich'd, and flying to others, whither they are allur'd by the cheapness of provisions and labour; till they have enrich'd these also, and are again banish'd by the same cause' (Hume 1752: 43). Istvan Hont has drawn attention to the significance of this line of argument for all the political economists of the Scottish Enlightenment (see Hont 2005: 267-322). Hume reaffirmed it in debate with Josiah Tucker in 1758. In a letter to Kames Hume made it clear that he did not see Scotland as being in direct economic competition with England. The question was how Scotland might 'share [with England] in wealth and industry'. And, so he told Kames, he was glad to be able to indulge himself in hopes that Scotland possessed 'some advantages' that may enable it do so. Scotland should devote itself at first to 'the simpler kind of industry'. There was no reason to think that England would ever be able to 'annihilate or oppress' Scotland's commerce in the provisions it was naturally fitted to produce (Greig 1932: I 271).

4.6 Hont has underlined the fact that Hume's pessimism about the ability of a rich country like England to maintain its position indefinitely expressed itself in the 
language of traditional civic humanism. Hume was prepared to talk in terms of 'a happy concurrence of causes in human affairs, which check the growth of trade and riches, and hinder them from being confin'd entirely to one people' (Hume 1752: 43), thus apparently endorsing the idea that countries, like human beings, have a natural lifespan, and are bound in the end to decay and die. Hume did not accept that it was wealth and luxury that were responsible for the fatal weakening of a country that had achieved greatness, but he came close enough to that way of thinking to be attacked for his 'historical pessimism' by none other than Wallace, in his Characteristics of the Present Political State of Great Britain, published in 1758 as a rebuttal of John Brown's Estimate of the Manners and Principles of the Times (see Hont 2005: 289-91). Wallace also criticized Hume's reluctance to endorse banks and paper money as a means of helping Scotland toward prosperity. It may have been in order to clarify his understanding of the future of rich countries, and to distance himself from people like Brown, that Hume wrote a new essay, 'Of the Jealousy of Trade', for the 1758 edition of Essays and Treatises on Several Subjects. This essay reads more like a lesson for England than a lesson for Scotland. Its argument is 'that the increase of riches in any one nation, instead of hurting, commonly promotes the riches and commerce of all its neighbours; and that a state can scarcely carry its trade and industry very far, where all the surrounding states are buried in ignorance, sloth, and barbarism' (Hume 1764: I 361). It is an invaluable resource for those who believe that Hume is best characterised as an essentially cosmopolitan political thinker. It sees Hume pursue his project of reducing the usual antipathy of the English for France. It is a British subject, Hume says in conclusion, that he 'pray[s] for the flourishing commerce of GERMANY, SPAIN, ITALY, and even FranCE itself' (Hume 1764: I 365). Hume was not the only Briton arguing against the idea that trade is a zero-sum game and that France's gains must be England's losses. Tucker was another. Even so it has been argued -- by Duncan Forbes -- that there is a close connection between Hume's cosmopolitanism and his Scottishness. Cosmopolitanism, according to Forbes, 'is a feature of the Scottish mind and Scottish civilization that the Englishman never fully grasps'; it prompted to Hume always to be concerned with English politics, and English history, 'in the context of a wider European experience and from a metropolitan point of view' (Forbes 1963: 282; see also Forbes 1978). The idea here, presumably, is that it was being Scottish that gave Hume his detached and nonpartisan perspective on England and its prospects.

4.7 As Forbes is aware, Hume had an equally detached perspective on Scotland itself. His Scottishness was forward-looking, and, as we will see in the next section of this chapter, was untainted by sentimentality about the past. Hume believed in progress to the extent that he was prepared to accept that the modern world was, politically speaking, preferable to the ancient. The great achievement of modern world was the rule of law -and Hume was certainly cosmopolitan enough to believe that it was not in eighteenthcentury England that the conditions of the possibility of the rule of law had been revealed for the first time. The 'civilized monarchies' of Europe had developed to a point where, de facto, the rule of law coexisted with absolute monarchical power. In the modern world the form of government did not matter very much, if at all. This complete lack of sympathy for those who dreamed of a return to the republicanism of the ancient world makes it hard to understand why Hume closed Political Discourses with an update of James Harrington's description of the ideal republic in Oceana. There are in fact two puzzles here. The first is why Hume was at all interested in the question of what the 'most perfect' form of government might be, and the second is why he gave that question a republican answer.

4.8 John Robertson has argued that 'Idea of a Perfect Commonwealth' is to be understood as a 'model', as a standard to direct legislative reform. He has argued also that 
the essay is best read as an engagement on Hume's part with the republicanism, not of Harrington, but rather of Andrew Fletcher of Saltoun (see Robertson 1983). Fletcher, on Robertson's reading, sought to answer precisely the questions we have seen Hume address in the present section of this essay. He was worried about Scotland's poverty, and its dependence on England in the context of a union of the two nations, and, in $A n$ Account of a Conversation concerning a Right Regulation of Governments for the Common Good of Mankind, published in 1704, had proposed a new model of the European state system such as would protect Scotland's freedom. But the spirit of Fletcher's republicanism was taken from the ancient world. Hume's model for reform, by contrast, was 'a projection into the future' (Robertson 1983: 175), an argument that Fletcher was wrong in his conviction that commerce was of its nature a threat to liberty. More precisely, according to Robertson, it was an argument that a modern commercial state had the potential to realise not just liberty in the form the rule of law, but also a more active and 'civic' mode of self-government. Robertson admits, however, that it is not obvious that Hume was really optimistic to enough to believe that Britain would ever become something approximating to a perfect commonwealth. His view seems usually to have been that, one way or another, Britain, meaning both Scotland and England, was on the way toward becoming an absolutist monarchy. Such was the argument of the 1741 essay 'Whether the British Government inclines more to absolute Monarchy, or to a Republick', and such also are the sentiments of letters -- to which we will return below -- written in the late 1760 s and early 1770 s.

5.1 Commentary on Hume's History has tended to focus upon its dismantling of the favourite myths of English Whiggism. Prominent among these were the notions of an Anglo-Saxon government in which power was shared between crown, nobility, and commons, of an enduring common law tradition which survived the Norman invasion (meaning that it was not proper to speak in terms of a Norman conquest), of the recognition by the crown of a rightful and traditional place for the commons in parliament as early as 1265 , and of the late Tudor period as having seen a full flowering of English liberty which the Stuarts subverted and which the Revolution of 1688 restored. Work by Forbes, Phillipson, Pocock, and others has detailed the damage done by Hume to the possibility of using English history for Whig political purposes (see especially Forbes 1975, Phillipson 2011, Pocock 2000). Yet, as Colin Kidd has made clear (see Kidd 1993), there was such a thing as Scottish version of Whig history as well, a reading of Scottish history premised on a distinctively Scottish version of the idea of an ancient constitution with an enduring political significance for later times. According to sixteenth-century opponents of royal absolutism such as George Buchanan, the traditional Scottish model of government was that of a monarchy limited by a combination of the nobility and the clan chiefs. In the seventeenth century Scottish Whiggism developed out of the belief that this model had been disastrously upset by the 1603 Union of the Crowns. The continuous violence of the seventeenth century had been the result of the fact that, with the king and court moved south to London, the constitution had lost its balance. There was no longer constraint on either the rapacity of the nobility or the disorderliness of the people. Nor was there confidence that Scotland's Presbyterian national church was safe from the increasingly Erastian religious policy of 
the Stuarts. The solution to these problems, Scottish Whigs claimed, lay in a union of parliaments, and a constitutional framework that would return Scotland to the rule of law, and also provide a guarantee of her autonomy in matters of religion. Andrew Fletcher's republicanism was born of his dissatisfaction with this case for a union of parliaments. He did not believe in the version of Scottish history on which it was based, and held that it was necessary to look further afield for the right political model for a modern Scotland. Debate about the Whig version of Scottish history continued after the 1707 Act of Union, and can be assumed to have been one of the contexts, at least, for the History that Hume published between 1754 and 1762.

5.2 Hume first conceived of himself as writing a history of Great Britain. This history would begin in 1603 and would end, perhaps, with the Hanoverian succession in 1714. It would be, necessarily, a history of Scotland as well as a history of England. And the existence of Scottish form of Whiggism meant that the decision to start in 1603 would be as significant in North Britain as in South. The implication was that on neither side of the Tweed was there a need to begin with an account of time-honoured liberties put in danger by the unbridled extension of royal prerogative pursued by James I and Charles I. The eventual resolution of the great crisis of the seventeenth century was no more in Scotland than it was in England a matter of the recovery of freedoms that had existed in the past. On the contrary, so the logic of Hume's historical argument dictated, the system of liberty implemented in the wake of 1688 was completely new. It was a corollary of the argument that the disorder in Scotland after 1603 was not, as the Whigs would have it, caused by the Union of the Crowns. It was, rather, endemic to Scottish society as such. Hume confirmed this view of Scotland in the volumes of the History of England on the Tudor period. Prior to the seventeenth century, he asserted there, Scotland was barely a state at all. It was 'rather to be considered as confederacy, and that not a close one, of petty princes, than a regular system of civil polity' (Hume 1759a: 96).

5.3 Hume depicted Scotland at the time of the accession of James I and VI as a scene of 'feudal anarchy' (see esp. Hume 1754-57: I 58-61). As in the Archibald Stewart pamphlet, he presented Scotland as comprising two different 'races', Highland and Lowland. At this time, though, the manners of these races were more or less the same. Everywhere the Scots 'lived ... in a manner somewhat disorderly; governed by antient customs more than by laws, and attached to their own families more than to their prince or country' (59). Even before 1603, according to Hume, a Scottish king possessed little real power. The 'dawn of the arts' that had appeared in the rest of Europe in the previous century had been prevented from introducing order and obedience in Scotland by the particular way in which the Reformation arrived there. What Hume terms 'protestant fanaticism' only made the country harder to govern, for it weakened the authority of the nobility without adding to the power of the crown. 'Determined enemies to monarchy by principle as well as inclination,' Hume explained, 'the religious orators placed a vanity in affronting their prince, and would acknowledge no sovereign but Christ, whose throne, being established in heaven, imposed little restraint upon them' (61). While he was only king of Scotland, James managed the situation prudently, but as soon he was king of England too he made the catastrophic mistake of trying to impose upon Scotland the English form of worship and church governance -- which he, rightly, took to be more consonant with royal power. In the first edition of the first volume History of Great Britain Hume described in some detail the foolish measures taken by James to this end, and, in his account of the reign of Charles I, went some way toward justifying Scottish resistance to royal incursion upon their ecclesiastical privileges. He also detailed the ways in which Charles II and James II reiterated the mistakes of the early Stuarts, pursuing policies which were bound to be responded to with violence. The Revolution of 1688 thus 
appears in Hume's narrative as what the Whigs claimed it was, a necessary means of ridding Scotland of tyranny. But Hume was explicit that it was at the same time an entirely novel departure for the Scots. 'The Scotch nation ...', he claimed, 'had but very imperfect notions of law and liberty; and scarce in any age had they ever enjoyed an administration, which had restrained itself with the proper boundaries. By their final union alone with England, their once hated antagonist, they have happily attained the experience of a government perfectly regular, and exempt from all violence and injustice' (Hume 1754-577: II 187).

5.4 There is less about Scotland in the second, 1759, edition of The History of Great Britain. ${ }^{11}$ By this time Hume was already worried that his history looked more Whiggish than he meant it to be. His anxiety on this score, his desire to be completely impartial in his presentation of the seventeenth century in particular, prompted Whigs in London to call him a Tory. In fact, as he told his friend John Clephane in September 1757, in some quarters he earned 'the reproach of the most terrible ism of them all, that of Jacobitism' (Greig 1932: I 264). This was of course nonsense. The fact that Hume was sceptical about the stories that Whigs told themselves did not mean that he was willing to believe in divinely ordained royal authority, handed down in an unbreakable chain from one king to his natural heir, and impossible to resist without criminal impiety. Hume made this perfectly clear in his presentation of the case of Mary Queen of Scots in the Tudor volumes of the History of England. By the middle of the eighteenth century, in the aftermath of the '45, Mary and her treatment at the hands of Elizabeth had become more than ever terrain on which Scottish Jacobites continued by proxy the struggle against Hanoverian usurpation. Hume made it clear that he did not believe that as an ordained monarch Mary could not legitimately be put on trial by anyone, nor that the right of hereditary succession meant that she had (through Henry VIII's elder sister) a claim to the English throne as well as the Scottish one. Mary was no martyr, no saintly innocent. Hume argued that she was guilty of involvement both in the murder of her first husband Lord Darnley and in the 1586 Babington plot against Elizabeth. In a long and closelyreasoned footnote he gave no fewer than sixteen reasons to accept the authenticity of the 'Casket Letters' implicating Mary in Darnley's death.

5.5 On the other hand, Hume sought to distinguish his account of Mary's life and death from the one favoured by most Scottish Whigs. He wanted his reader to notice that at no point did he rely upon what had been written about Mary by Knox, Buchanan, and Melville. To have done so would have made it too easy for Mary's supporters to dismiss his narrative as just another instance of Presbyterian bias and bigotry. Hume did not stint in his description of Mary's virtues, and of the beauty of her person. She was an 'amiable princess' while her persecutor Knox was a 'rustic apostle'. '[S]he seemed to partake only so much of male virtues as to render her estimable', he rhapsodized, 'without relinquishing those soft graces which compose the proper ornaments of her sex' (Hume 1759a: 622). His depiction of her death was just as overt in its attempt to enlist the reader's sympathy as his depiction of the execution of Charles I. Moreover, if she was guilty, so also were those who condemned her to death. Elizabeth was according to Hume an 'excellent hypocrite' in the way she had her half-sister executed and then pretended to be angry at those who had done her bidding. As so often in Hume's History, the reader of his portrait of Mary is pulled back and forth between opposing perspectives, and prevented from being able to settle into any of the usual ways of thinking, and feeling, about the issue. Hume was not alone in wanting to deal with Mary in a new way.

\footnotetext{
${ }^{11}$ Compare, for example, Hume 1754: 58-61 with Hume 1759b I: 52-3. Also, e.g., there is no account of the Articles of Perth in the 1759 version of the reign of James I.
} 
There is a similar refusal to toe either of the usual party lines in William Robertson's History of Scotland, published in the same year as Hume's Tudor history. ${ }^{12}$ And the fact that he and Robertson remained friends despite the fact that they were in direct competition for the title of Britain's best historian was a cause of celebration to Hume. 'Had you \& I been such Fools to have given way to Jealousy, to have entertaind Animosity \& Malignity against each other, and have rent all our Acquaintance into Parties', he wrote to Robertson, 'what a noble Amusement shoud we have exhibited to the Blockheads, which now they are likely to be disappointed of?' (Klibansky and Mossner 1954: 46). Hume and Robertson, like Hume and Wallace, and Hume and Balfour, were in alliance against those in Scotland who remained trapped in outdated, ossified modes of thought.

5.6 Robertson also shared Hume's scepticism about the Scottish Whig conception of a supposedly noble and free Scottish past. Scotland's kings had always been poor and weak, and had, like the Scottish people, been at the mercy of rapacious feudal lords. The feudal age had, for Robertson as for Hume, been an age not of freedom but of anarchy. In the 1750s, following the publication in 1748 of Montesquieu's De l'Esprit des Lois, feudalism had in fact come to be a matter of particular interest to Scottish historians. In 1757 John Dalrymple published An Essay towards a General History of Feudal Property in Great Britain, and a year later Kames brought out his Historical Law-Tracts. Both works sought to articulate what might be termed a British historical jurisprudence. They argued that Scottish and English law, despite their differences, had a common origin, and they were concerned to point out the respects in which Scotland was lagging behind its southern neighbour when it came to removing feudal impediments to a system of law adequate to a modern, commercial society. Earlier in the eighteenth century interest in feudalism had largely been the preserve of Tories concerned to show that the Norman invasion had been a conquest, and that henceforth the privileges of the people were to be understood as royal dispensations, revocable at the king's pleasure. English Whigs had downplayed the significance of feudal law, insisting that it did not supersede the Saxon common law tradition. The intense interest that Hume showed in English feudalism in the medieval volumes of the History of England is, it might be said, a distinctively Scottish element of his historiographical perspective.

5.7 In the works of Smith and Ferguson, in Robertson's Preface to his History of the Reign of Charles V, in Millar's Origin of the Distinction of Ranks, and indeed in Kames's Sketches of the History of Man, a historical and comparative jurisprudence was the foundation for universalist speculation about the history of civil society as such. Hume was, it might be said, distinctively un-Scottish in the fact that his history writing did not move in this direction. In his books there is no trace, for example, of the four-stage theory of history that begins with hunting and gathering and passes through shepherding and agriculture to culminate in commerce. Once he left behind Book Three of the Treatise's comparatively sketchy account of the origins of property and justice, Hume showed no systematic interest in the 'natural history of society'. As Forbes pointed out (1963: 289), it is surely significant that he never even used the phrase. In this respect Hume's history writing was conservative. He remained attached to the narrative structure provided by the successive reigns of kings and queens. At the same time, however, his aim was often only to show how the doings of kings and queens had little effect on the country's fortunes, or had effects quite different from those intended. He depicted

\footnotetext{
${ }^{12}$ Robertson agreed with Hume that Mary was involved in Darnley's murder, but did not accept that she had a part in the Babington plot. Hume discussed this difference of opinion in a letter to Robertson of November 1758: see Greig 1932: I 287-90.
} 
England as in the grip of large-scale historical forces such as the decline of feudalism and the rise of the gentry and the commercial class, the Renaissance (or, 'the dawn of the arts'), the Reformation ('one of the greatest events in history' (Hume 1759: 116)), and the modern age's globalization of commerce. This was not the usual point of view of a writer of a general history of England. It was a point of view from which the usual business of praising some kings and statesmen and clerics and blaming others was apt to look pointless, if not absurd. It was the point of view, in other words, of the 'philosophical' historian: the historian who may have chosen to write about one particular country, but who placed that country in, if not a global, then certainly a European perspective. As Forbes puts it, Hume's History of England 'is not a history of English civilization, but of civilization in England' -- and 'the progress of civilization and "liberty" is a European, not an exclusively English theme' (Forbes 1970: 22-3).

5.8 Thus we return to Hume's supposed cosmopolitanism. The kind of cosmopolitanism characteristic of Hume, and also of historians such as Voltaire, Robertson, and Gibbon, is, according to Karen O'Brien, 'an attitude of detachment towards national prejudice ... and an intellectual investment in the idea of a common European civilization' (O'Brien 1997: 2). On O'Brien's view, as he pushed his History backwards in time, Hume came to be increasingly interested in the anomalousness of the English case, in the peculiar fact that as feudalism collapsed England did not follow the path towards a modern and civilized form of absolutism. As we have seen, Forbes (though not O'Brien) traces a link between Hume's cosmopolitanism and his Scottishness. But to the extent that the Scots, as Kidd shows, had their own form of parochial, illusion-laden Whiggism, Hume's Scottishness cannot by itself explain the kind of history that he wrote. There is in fact nothing about the complete History of England to identify it as the work of a Scotsman. This is more than a matter of Hume's enduring concern with ridding the book of 'Scotticisms'. Hume's goal was nothing less than that of replacing Rapin as the historian who could make sense of English history for the benefit of all of Europe. '[W] hat must foreigners do to get some notion of our history?' Hume asked Horace Walpole in August 1758 (Greig 1932: I 285). His History was his answer to his own question. Earlier in the same letter Hume confessed that he had been 'seduc'd by the example of all the best historians even among the moderns, such as Matchiavel, Fra paolo, Davila, Bentivoglio' (284). ${ }^{13}$ This explained not only his failure to quote his authorities in the first edition of the History of Great Britain but also the character of his ambitions as a historical writer. He intimated to Walpole that he wanted to join the historians who were essential reading for 'the learned throughout all Europe'. To that end it was essential that the differences be obvious between his History and the many books of those, Scots as well as Englishmen, who sought to do no more than advance the cause of a particular party or church.

\footnotetext{
${ }^{13}$ For useful commentary on this remark, see Wootton 2009. As Wootton puts it, like Sarpi (i.e. 'Fra paolo') especially, Hume 'sought to address a new audience: neither of politicians nor of antiquarians, but of those who aspired to participate in polite conversation' (451).
} 
6.1 It is possible that from the very beginning Hume was at odds with the spirit of his countrymen when it came to religion. Hume told Boswell that he was religious enough when young to use a popular devotional tract, The Whole Duty of Man, as a means of selfexamination. He would go through it checking which vices he was subject to.

Presumably this was one of the religious books to be found in the family library at Ninewells. But The Whole Duty of Man, published in England in 1658, was anti-Puritan and anti-Calvinist in spirit, and thus there is evidence here that the religion he was brought up into was, for the time and place, relatively liberal. It can be supposed that The Whole Duty of Man was approved by a man who must have played an important role in Hume's early years, the husband of his father's sister, George Home, minister at Chirnside from 1704 to 1741 . At some point in his early teens, however, Hume lost his belief. He looked into the philosophical arguments for the existence of God to be found in Newton and Clarke, and found them wanting. According to some commentators, most recently Paul Russell, Hume was henceforth an atheist (see Russell 2008: 279-289). It is not obvious, however, that Hume believed in an alternative, non-religious, theory about the origins of the universe and about the nature of the fundamental powers at work in the world as we experience it. There seems to have been little affinity on this score between Hume and radical French writers like d'Holbach and Helvétius. Gibbon reported that such men 'laughed at the scepticism of Hume' (Gibbon 1984: 136). It is arguable that Hume's stance was rather that of a sceptic who believed in no grand metaphysical schemes whatsoever, whether theistic or materialist, who regarded all the big questions as unanswerable, and who held, like Philo in the Dialogues concerning Natural Religion, that we would do well instead to 'confine our speculations to trade, or morals, or politics, or criticism' (Hume 1779: 26).

6.2 In any case, the important thing for present purposes is not what Hume's personal beliefs were, but rather how he chose to write about religious subjects. His Scottish context is, perhaps, more important to understanding Hume in this connection than it is with regard to any of the topics covered so far in this chapter. Hume may have been increasingly concerned with how he was received on the pan-European stage, but throughout his literary career he found himself constantly drawn into the religious disputes of his native country, and when he wrote about religion, he seems always to have had those disputes close to the front of his mind. It would not be an exaggeration to say that Lowland Scotland, especially during the second and third quarters of the eighteenth century, was the site of an ongoing religious war. The conflict was between a modernizing, moderate understanding of Christianity, intent on harmonizing Scotland's religiosity with the spirit of the new age of politeness and commerce that had announced by the 1707 Act of Union, and a traditionalist orthodoxy animated by the spirit of the great covenanting movement of the previous century. It was a conflict played out in every aspect of Lowland life. It was a struggle for Scotland's soul. The deepest question was what kind of country was Scotland to become after the Union and the Hanoverian succession. Had the Covenanters been right to believe that the Reformation in Scotland had made possible a particularly close relationship between the Scottish people and God, a relationship that was imperiled by the erastianism and lax morals and depraved tastes of the English, or was the Union a God-given chance for Scotland to leave the extremism and violence of the past behind forever? Whether Hume was an atheist or a sceptic in his private beliefs, this was a question that he could not avoid. It was also a question that he could answer in only one way. If Hume probably did not care much about the more purely doctrinal elements of the conflict, nor about the vexed matter of how ministers were elected to their charges, he cared a great deal about wider cultural questions concerning, for example, university appointments, the status of the arts, and general freedom of expression. Just as he instinctively sided against the Jacobites during the '45 
and afterwards, so also every fibre of his being set him at odds with the Calvinist reactionaries of what became known as the 'Popular' party of the Church of Scotland.

6.3 It is possible, as we have seen, that Hume's family favoured the religion of the 'Moderate' party. ${ }^{14}$ It is certain that, from the first, his friends did as well. Hutcheson, for instance, played an important role in the first stages of the battle for the modernization of the religious and moral culture of Scotland. So did another friend of Hume's at Glasgow, the professor of divinity William Leechman. The appointments of both men were opposed by Calvinist traditionalists. That they got their jobs anyway was a sign that things were changing. They knew, however, that the process of change could be drastically slowed, perhaps even reversed, by their opponents. There was no reason to think in the 1730s and 1740s that it was certain which way Scotland would turn. This was, perhaps, why Hutcheson and Leechman could not support Hume when his name was put forward for the Edinburgh chair of moral philosophy in the summer of 1744. In fact there was probably more than one reason for men like Hutcheson and Leechman, and also the principal of the University, William Wishart (who had also been on the receiving end of persecution by the orthodox), to think that Hume was not the right person for the job. For one thing, Hume could not be relied upon to take seriously enough the question of articulating and defending the kind of religion they wanted to see prevail. A professor of moral philosophy, after all, was obliged to lead his students through the arguments of natural religion. But also there was the fact that Hume was bound to used by the party of Calvinist orthodoxy as a means of discrediting the modernizers and moderates. He was easily associated with them, and it was imaginable that it would be insinuated as a result that they condoned, perhaps even sympathized with, the 'Heresy, Deism, Scepticism, Atheism \&c \&c \&c' that Hume was charged with as soon as his candidacy was announced (Greig 1932: I 57).

6.4 We can only speculate about why, exactly, Hutcheson, Hume, and Wishart opposed Hume's candidacy for the Edinburgh chair. The important thing is that it is not necessary to take Hume's failure to be appointed as a simple instance of philosophical freethinking pitted against conservative religiosity (see Stewart 1994). Matters in Scotland at the time were more complicated. There was also the political dimension of the affair (see Emerson 1994). University appointments were contests of strength between the Argyll interest and its 'Squadrone' rival, and in this instance, the Argathelians lost. When, in the winter of 1751-52, Hume's name was put forward for the logic chair at Glasgow, he did not even get to the stage of getting Argyll backing. In neither case, however, does Hume seem to have much wanted the job. 'I was never very fond of this Office of which I have been disappointed', he told Kames in June 1745, 'on account of the Restraint, which I forsaw it wou'd have impos'd on me' (Klibansky and Mossner 1954: 17). It is hard to imagine him celebrating getting the Glasgow chair with the enthusiasm with which he welcomed election to the position of Librarian to the Faculty of Advocates in February 1752 (see the letter to John Clephane dated 4 February (Greig 1932: I 164-67)).

6.5 As part of the effort to ensure that Hume was not appointed to the Edinburgh chair, Wishart put out a pamphlet that represented the philosophy of the Treatise as dangerously sceptical as regards commonsense, morality, and religion. Hume responded point by point in a text that was published by Kames, possibly without Hume's knowledge, as A Letter from a Gentleman to his Friend in Edinburgh. As mentioned above, the episode prompted Hume to reconsider the sceptical dimension of his account of the human understanding, or rather, to reconsider the way in which he had presented

\footnotetext{
${ }^{14}$ For a study of the 'Popular' party, see McIntosh 1998. The best general account of the cultural dimension of the 'Moderate' party is Sher 1985.
} 
his scepticism in the Treatise. The result was Philosophical Essays concerning Human Understanding, published in 1748, and retitled An Enquiry concerning Human Understanding ten years later. This was not, though, in any sense a compromise on Hume's part. In no sense did the failure to win the Edinburgh chair cause Hume to tone down his views. On the contrary, Hume now included sceptical treatments of the rationality of belief in both natural religion and testimony of miracles. And he playfully pretended to cover himself from the charge of irreligion by frequently, like a good Calvinist, making use of the language of fideism to point out that the most secure foundation of religion is faith nor reason. He told Kames in February 1748 that he was 'indifferen[t] about all the consequences that may follow' (Greig 1932: I 111). It is possible that at this point in his career -- he was just about to leave with St. Clair for Vienna and Turin -- he felt he had left Scotland's religious squabbles behind him. If that was so, he was mistaken. The next year he returned to Ninewells, and some time soon afterwards began writing a work that dramatizes the situation of a sceptic caught in the crossfire between moderate religion and orthodoxy.

6.6 Though not published until three years after Hume's death, Dialogues concerning Natural Religion existed in draft form as early as spring 1751. Hume told Gilbert Elliot that he imagined that a dialogue on such a subject was best composed by two people. Had he and Elliot lived near each other, they might have tried this. 'I shou'd have taken on me the Character of Philo', he wrote, 'which you'll own I coud have supported naturally enough' (Greig 1932: I 154). Elliot, he continued, 'would not have been averse' to the character of Cleanthes -- and nor, perhaps, would a number of those among the Moderates who became Hume's friends, including Wallace, Ferguson, Robertson, John Home, Hugh Blair, and Alexander Carlyle. They were all men who regarded practice, not doctrine, as the essence of the Christian religion, and, when it came to the defence of the central principles of theism, were confident in the capacity of experimental natural philosophy to give religion a rational foundation. The part of Demea, on the other hand, who after a rather clumsy defence of a priori religious argument asserts that each man's feeling of the truth of religion derives in the first instance from 'a consciousness of his imbecility and misery, rather than from any reasoning' (Hume 1779: 171), might have been taken by a member of the 'Popular' party. For a large part of the Dialogues Hume presents Philo and Demea as in alliance against the probabilistic, inductivist arguments put forward by Cleanthes, but at the end, Demea leaves the room, finally aware that Philo might be 'a more dangerous enemy than Cleanthes himself' (223), and the stage is set for Philo to try to convince Cleanthes that the disagreement between them about what can be rationally asserted about the cause of the universe is a mere 'dispute of words'. This can be read as an attempt on Hume's part to convince his friends among the men of moderation that, were they to understand their own religious claims better, they would see that Hume believed just the same things that they did. But the conclusion of the Dialogues also registers Hume's awareness that full reconciliation between sceptic and theist was in truth not possible. The final, insurmountable, or at least unsurmounted, disagreement between Philo and Cleanthes concerns the practical role of religion. As Philo sees it, the choice is between genuinely rational (and extremely minimal) religion on the one hand, a religion which crucially has no practical consequences whatsoever, and rank superstition on the other. Cleanthes has a more nuanced view. 'Religion, however corrupted,' he says, 'is still better than no religion at all' (242). Religion has a practical role to play in ordinary life, he believes, and if elements of superstition help it play that role, then so be it. This is, perhaps, an acknowledgment on Hume's part of a crucial difference between him and his Moderate friends: they were much more involved than he cared to be in the business of making a difference to, improving, the lives that people lived. 
6.7 Hume's other great contribution to the philosophy of religion, 'The Natural History of Religion', can also be read as an intervention in the quarrel between the Moderates and the Popular Party. It was being dragged into that quarrel in 1755 that seems to have prompted Hume to publish the 'Natural History', a work that was probably written between 1749 and 1751, at the same time as the Dialogues. Hume, along with Kames, was threatened by the Popular Party with excommunication from the Church of Scotland during the meeting of the General Assembly of May 1755, and again the following year. It is doubtful that those who made this threat really cared that much about the fate of either Hume or Kames. It is more likely that what they wanted was to involve the Moderates in the controversy, and to get them to discredit themselves -- as the Popular Party saw it -- by defending their scandalous friends. If so, they got what they wanted. The Moderates rallied behind Hume and Kames and ensured that the move against them never reached the floor of the General Assembly (see Sher 1985: 65-74). Hume may have imagined that 'The Natural History of Religion' would help in the general struggle against the forces of reaction and intolerance. It added a historical dimension to the opposition between philosophical (or, 'true') religion and superstition, and, while for the most part it concentrated on Catholicism and Islam as instances of superstition, it included a footnote quoting at length from the Catholic Chevalier Ramsay's indictment of the Calvinist doctrines of eternal reprobation and predestination (see Hume 1757: 99-102). The fact that in 1756 the forces of reaction switched their attentions from him and Kames to John Home and his play Douglas prompted Hume to dedicate the work in which the 'Natural History' appeared, Four Dissertations, to Home. The dedication -- the only one Hume ever wrote -- gives a clear sense of the importance Hume attached to being able to live on amicable terms with the men of the Moderate party. He wrote of a 'true liberty, of which antient times can alone afford us an example', 'the liberty of thought, which engaged men of letters, however different in their abstract opinions, to maintain a mutual friendship and regard; and never to quarrel about principles, while they agreed in inclinations and manners' (Hume 1757: ii). The dedication was meant to be understood as a renewal of this ancient practice. The 'Natural History', then, should not be read as a crude broadside assault on religion as such. It is in fact an argument to the effect that what needs to be attended to are the different historical manifestations of the religious impulse, and it allows that some forms of religion are very much more corrupt, and pernicious, than others. It is just possible that Hume expected the Moderates to welcome it as a contribution to their struggle against the Calvinists.

6.8 If this is what he expected, he was naive. There was much in the 'Natural History' that evinced the ironical detachment from religious questions that set Hume apart from almost all of his contemporaries. It was obvious that for Hume religion was an entirely speculative issue, not something that was of any relevance to how he lived his life. And in fact, Hume probably wanted not so much agreement with the argument of the 'Natural History', or with the argument of his other writings on religion, as a willingness in others to take the argument seriously, to engage with it on its own terms. This, so the dedication to Four Dissertations suggests, was what really mattered to him. $\mathrm{He}$ was not always disappointed in this desire. His Moderate friends in Edinburgh as a rule refused to engage with him. Their response to the Dialogues was to hope that it would never be published. But there were those in Scotland prepared to argue back on behalf of rational religion, most notably the Aberdeen professor George Campbell in A Dissertation on Miracles. In June 1762 Hume wrote to Campbell to compliment him on the 'ingenuity' and 'great learning' of his book. It has very seldom happened, Hume noted, 'that controversies in philosophy, much more in theology, have been carried on without producing a personal quarrel between the parties' (Greig 1932: I 360). Hume also wrote 
to Reid to acknowledge the seriousness of the challenge to scepticism in general, including scepticism about religion, presented in An Inquiry into the Human Mind on the Principles of Common Sense (see Wood 1987). Not every Scottish critic of Hume on religion, in other words, attacked him with the ad hominem ferocity of Beattie in An Essay on Truth, and Hume was alive to the differences between his various opponents. Hume's most severe critics, on the other hand, Beattie among them, sought to efface the differences between Hume and those who openly declared themselves hostile to Christianity. In his portrait of Beattie, Joshua Reynolds paired Hume with Voltaire. Yet Hume lacked Voltaire's sense of the vileness, l'infame, of the Christian religion as such. His view, made most clear in the History of England, was that religion tended to be source of dangerous delusion, intolerance, and violence. It was often a means whereby bad people concealed their worst vices. Human society in general would doubtless be better off without it. But, so the 'Natural History' suggested, the origins of religion lay deep within human nature, so deep that a world without religion was inconceivable. The most pressing question, then, was the political one of how religion was to be managed so as to cause as little harm as possible. The Presbyterian model of church governance was endorsed by Hume in 'Idea of a Perfect Commonwealth', but only given the overall supervision of the clergy by the supreme magistrate. Without such supervision -- which was what the Popular Party in Scotland abhorred most of all -- "tis folly to think any free government will ever have security or stability' (Hume 1752: 298). Such, in any case, was the lesson of history of post-Reformation Scotland.

7.1 In the summer of 1769 Hume returned to Edinburgh after two and a half years in London. He had been Deputy Secretary of State in the Department between February 1767 and January 1768, and had then remained in London for eighteen further months. Presumably he stayed on simply because he was enjoying living there. He was, he told Elliott, 'dining at all the great Tables that remain in London' (Greig 1932: II 184). But this was the time of the riots for 'Wilkes and Liberty', and anti-Scottish sentiment was everywhere on the streets and in the press. Hume headed north with relief. In October he wrote to Elliott that he was in Edinburgh 'Body \& Soul, without casting the least Thought of Regreat to London, or even to Paris' (Greig 1932: II 208). The time he had spent in Paris between 1763 and 1766 had inspired him for a while with the idea of retiring in the end to the City of Light. He had written from Paris in 1764 that he conceived of himself as a 'Citizen of the World' (Greig 1932: I 470), glad to be out of Britain both North and South. Now, though, it seemed unlikely that he would ever again so much as cross the Tweed. The madness of the London mob, exacerbated so he thought by the reluctance of the government to enact measures as draconian as the situation called for, made Edinburgh feel like a haven of calm and sanity. From there he watched with equanimity as crisis in London was followed by crisis in the American colonies. His letters of the early 1770s repeatedly express confidence that any attempt to impose British rule by force on the Americans was bound to be a disaster. Sometimes his pessimism generalized into the conviction that the post-1688 constitutional experiment had been a failure, and that there was bound soon to be a complete collapse of political order, to be followed, inevitably, by tyranny of one kind or another. This was where a populist politics of imperial expansion would inevitably lead. Hume pretends in his 
letters that he doesn't care, that in fact he welcomes the coming catastrophe. This was, as John Pocock has observed, 'very much a view from Edinburgh' (Pocock 1985: 125). Late in life Hume seems to have felt a renewed sense of all that differentiated him from the English. This did not mean that he stopped feeling British. It meant merely that he was once again sharply aware that he was Scottish, and that the mistakes being made in London were, for the most part, being made by Englishmen.

7.2 There was a literary dimension to the view from Edinburgh. When, in the spring of 1776, Gibbon published the first volume of the Decline and Fall of the Roman Empire, Hume wrote to him to express his surprise that such a performance was the work of an Englishman. It seemed to him, he told Gibbon, 'that your Countrymen, for almost a whole Generation, have given themselves up to a barbarous and absurd Faction, and have totally neglected all polite Letters', so much so that 'I no longer expected any valuable Production ever to come from them' (Greig 1932: II 310). Scotland had overtaken England when it came to literature, and especially when it came to history. In August 1770 he had told his publisher William Strahan that he believed that this was 'the historical Age' and that Scotland was 'the historical Nation'. There were at the time 'no less than eight Histories on the stocks in this Country' (Greig 1932: II 230). 'The best Book, that has been writ by any Englishman these thirty Years', he opined in January 1773, 'is Tristram Shandy, bad as it is' (Greig 1932: II 269). Hume took a keen interest in all that was published by his Scottish contemporaries. He gave Smith's Wealth of Nations an enthusiastic welcome, but on his death bed he also took up Campbell's recently published Philosophy of Rhetoric. This is a reminder that 'Enlightenment' in Scotland in the eighteenth century was not a matter of the success of any one particular system of philosophy, or of the implementation of any one social and political programme. Campbell and Wallace were just as much part of it as were Hume and Smith. Enlightenment in Scotland can be best defined, perhaps, in terms the ability and willingness of a remarkable number of Scots to take part in a conversation about questions philosophical, political, historical, scientific, and critical, and to keep that conversation going in a spirit of open-mindedness, politeness, and elegance. Hume was always party to the conversation, and he rejoiced in the fact that it did not usually matter whether or not anyone agreed with what he said. 


\section{BIBLIOGRAPHY}

[Anon.] (1725). The Physiological Library begun by Mr. Steuart. Edinburgh.

Barfoot, M. (1990). 'Hume and Culture of Science in the Early Eighteenth Century', in M. A. Stewart (ed.), Studies in the Philosophy of the Scottish Enlightenment. Oxford: Clarendon Press.

Box, M. A., Harvey, D., and Silverthorne, M. (2003). 'A Diplomatic Transcription of Hume's "Volunteer Pamphlet" for Archibald Stewart: Political Whigs, Religious Whigs, and Jacobites'. Hume Studies 29: 223-266.

Brandt, R. (1977). 'The Beginnings of Hume's Philosophy', in G. P. Morice (ed.), David Hume: Bicentenary Papers. Austin, TX: University of Texas Press.

Broadie, A. (2012). Agreeable Connexions: Scottish Enlightenment Links with France. Edinburgh: John Donald.

Caffentzis, C. G. (2001). 'Hume, Money, and Civilization: or, Why Was Hume a Metalist?', Hume Studies 27: 301-36.

Emerson, R. (1994). "The "Affair" at Edinburgh and the "Project" at Glasgow: The Politics of Hume's Attempts to Become a Professor", in M. A. Stewart and J. P. Wright (eds.), Hume and Hume's Connexions. University Park, PA: Pennsylvania State University Press.

Emerson, R. (2008). 'The Scottish Contexts for David Hume's Political-Economic Thinking', in C. Wennerlind and M. Schabas (eds.), David Hume's Political Economy. London and New York: Routledge.

Emerson, R. (2013). An Enlightened Duke: The Life of Archibald Campbell (1692-1761), Earl of Ilay, 3rd Duke of Argyll. Kilkerran: Humming Earth.

Forbes, D. (1963). 'Politics and History in David Hume', The Historical Journal 6: 280-323.

Forbes, D. (1970). 'Introduction' to David Hume, The History of Great Britain.

Harmondsworth: Pelican.

Forbes, D. (1975). Hume's Philosophical Politics. Cambridge: Cambridge University Press.

Forbes, D. (1978). 'The European, or Cosmopolitan Dimension in Hume's Science of Politics'. The British Journal for Eighteenth-Century Studies 1: 57-60.

Gibbon, E. (1984). Memoirs of My Life. Ed. Betty Radice. Harmondsworth: Penguin.

Greig, J. Y. T. (ed) (1932). The Letters of David Hume. 2 vols. Oxford: Clarendon Press.

Harris, J. A. (2009). 'Of Hobbes and Hume'. Philosophical Books 50: 38-46.

Hont, I. (2005). Jealousy of Trade: International Competition and the Nation-State in Historical Perspective. Cambridge, MA: Harvard University Press.

Hume, D. (1739-40). A Treatise of Human Nature. 3 vols. London.

Hume, D. (1740). An Abstract of a Book lately Published; Entituled, A Treatise of Human

Nature, \&c.. London.

Hume, D. (1741). Essays, Moral and Political. Edinburgh. 
Hume, D. (1748). Three Essays, Moral and Political. London.

Hume, D. (1752). Political Discourses. Edinburgh.

Hume, D. (1754-1757). The History of Great Britain, Under the House of Stuart. 2 vols.

London.

Hume, D. (1757). Four Dissertations. London.

Hume, D. (1759a). The History of England, Under the House of Tudor. London.

Hume, D. (1759b). The History of Great Britain, Under the House of Stuart. 2nd edn. 2 vols.

London.

Hume, D. (1764). Essays and Treatises on Several Subjects. 2 vols. London.

Hume, D. (1777a). The Life of David Hume, Esq. Written by Himself. London.

Hume, D. (1777b). Essays and Treatises on Several Subjects. 2 vols. London.

Hume, D. (1779). Dialogues concerning Natural Religion. London.

Kemp Smith, N. (1941). The Philosophy of David Hume: A Critical Study of its Origins and Central Doctrines. London: Macmillan.

Kidd, C. (1993). Subverting Scotland's Past: Scottish Whig Historians and the Creation of an AngloBritish Identity, 1689 - c. 1830. Cambridge: Cambridge University Press.

Klibansky, R., and Mossner, E. C. (eds.) (1954). New Letters of David Hume. Oxford: Clarendon Press.

McIntosh, J. R. (1998). Church and Theology in Enlightenment Scotland: The Popular Party, 1740-1800. East Linton: Tuckwell.

Moore, J. (1994). 'Hume and Hutcheson', in M. A. Stewart and J. P. Wright (eds.), Hume and Hume's Connexions. University Park, PA: Pennsylvania State University Press.

Mossner, E. C. (1943). Forgotten Hume: Le Bon David. New York:

Mossner, E. C. (1980). The Life of David Hume. 2nd edition. Oxford: Clarendon Press.

Norton, D. F. (1982). David Hume: Common-Sense Moralist, Sceptical Metaphysician. Princeton, NJ: Princeton University Press.

Phillipson, N. (1975). 'Culture and Society in the Eighteenth-Century Province: The Case of Edinburgh and the Scottish Enlightenment', in L. Stone (ed.), The University in Society:

Volume 2. Princeton, NJ: Princeton University Press.

Phillipson, N. (2011). David Hume: The Philosopher as Historian. London: Penguin.

O'Brien, K. (1997). Narratives of Enlightenment: Cosmopolitan History from Voltaire to Gibbon. Cambridge: Cambridge University Press.

Pocock, J. G. A. (1985). Virtue, Commerce, and History: Essays on Political Thought and History, Chiefly in the Eighteenth Century. Cambridge: Cambridge University Press.

Pocock, J. G. A (2000). Barbarism and Religion. Volume 2: Narratives of Civil Government. Cambridge: Cambridge University Press.

Raynor, D. (1991). 'Ossian and Hume', in H. Gaskill (ed.), Ossian Revisited. Edinburgh: Edinburgh University Press.

Robertson, J. (1983). 'The Scottish Enlightenment at the Limits of the Civic Tradition', in I. Hont and M. Ignatieff (eds.), Wealth and Virtue: The Shaping of Political Economy in the Scottish Enlightenment. Cambridge: Cambridge University Press. 
Robertson, J. (1985). The Scottish Enligbtenment and the Militia Issue. Edinburgh: John Donald.

Ross, I. S. (1972). Lord Kames and the Scotland of His Day. Oxford: Clarendon Press.

Russell, P. (2008). The Riddle of Hume's Treatise: Skepticism, Naturalism, and Irreligion. New York: Oxford University Press.

Sher, R. (1985). Church and University in the Scottish Enlightenment: The Moderate Literati of Edinburgh. Princeton, NJ: Princeton University Press.

Stewart, M. A. (1984). The Kirk and the Infidel. Lancaster: Lancaster University Press.

Stewart, M. A. (1997). 'Hume's "Bellmen's Petition": The Original Text'. Hume Studies 23: $3-8$.

Stewart, M. A. (2002). 'Two Species of Philosophy: The Historical Significance of the First Enquiry, in P. Millican (ed.), Reading Hume on Human Understanding: Essays on the First Enquiry. Oxford: Clarendon Press.

Stewart, M. A. (2005). 'Hume's Intellectual Development, 1711-1752', in M. Frasca-Spada and P. J. E. Kail (eds.), Impressions of Hume.

Tolonen, M. (2008). 'Politeness, Paris and the Treatise'. Hume Studies 34: 21-42.

Tolonen, M. (2013). Mandeville and Hume: Anatomists of Civil Society. SVEC.

Wood, P. B. (1987). 'Hume vs. Reid on Ideas: The New Hume Letter.' Mind 96: 392-98.

Wootton, D. (2009). 'Hume, "The Historian"', in D. F. Norton and J. Taylor (eds.), The Cambridge Companion to Hume, second edition. Cambridge: Cambridge University Press.

Wright, J. P. (2003). 'Dr. George Cheyne, Chevalier Ramsay, and Hume's Letter to a Physician'. Hume Studies 2003: 125-141.

Wright, J. P. (2012). 'Hume on the Origin of Modern Honour: A Study in Hume's Philosophical Development', in R. Savage (ed.), Philosophy and Religion in Enlightenment Britain. Oxford: Oxford University Press.

Zachs, W. (2011). David Hume 1711-1776: Man of Letters, Scientist of Man. Edinburgh. 